\title{
PENETAPAN PENGADILAN SEBAGAI BENTUK UPAYA HUKUM PADA PROSES EKSEKUSI
}

\author{
Kajian Putusan Nomor 1/Pen/Pdt/Eks/2017/PN.Mbo
}

\section{INJUNCTION AS A LEGAL REMEDY IN THE EXECUTION PROCESS}

\author{
An Analysis of Court Decision Number 1/Pen/Pdt/Eks/2017/PN.Mbo
}

\author{
Rio Christiawan \\ Fakultas Hukum Universitas 17 Agustus 1945 Jakarta \\ Jl. Sunter Permai Raya 36 Kota Jakarta Utara 14350 \\ E-mail: rchristiawan@gmail.com
}

Naskah diterima: 18 Januari 2018; revisi: 28 November 2018; disetujui: 6 Desember 2018

http://dx.doi.org/10.29123/jy.v11i3.302

\begin{abstract}
ABSTRAK
Pengadilan Negeri Meulaboh melalui Putusan Nomor 12/Pdt.G/2012/PN.Mbo jo. Putusan Pengadilan Negeri Banda Aceh Nomor 50/Pdt/2014/PN.Bna jo. Putusan Mahkamah Agung Nomor 651 K/Pdt/2015, menghukum PT KA untuk membayar ganti rugi atas kerusakan lingkungan yang ditimbulkan sebagai akibat dari kebakaran hutan. Putusan Peninjauan Kembali Nomor 1 PK/Pdt/2017 yang dimohonkan PT KA juga menolak permohonan peninjauan kembali PT KA. Ketika Kementerian Lingkungan Hidup dan Kehutanan mengajukan perintah eksekusi, justru Pengadilan Negeri Meulaboh menerbitkan Penetapan Nomor 1/ Pen/Pdt/Eks/2017/PN.Mbo yang menunda eksekusi dan memberikan perlindungan hukum kepada PT KA, dengan alasan PT KA sedang mengajukan gugatan baru kepada pemerintah. Permasalahan dalam penelitian ini apakah Penetapan Nomor 1 Pen/Pdt/Eks/2017/ PN.Mbo dapat menunda putusan pengadilan yang telah berkekuatan hukum tetap. Metode dalam penelitian ini adalah yuridis normatif dengan pengambilan data secara kepustakaan dengan cara berpikir deduktif dalam melakukan verifikasi data. Bagian pembahasan
\end{abstract}

penelitian ini akan diuraikan bahwa penetapan dalam kasus PT KA ini akan menimbulkan ketidakpastian hukum dalam peradilan dan dikhawatirkan akan menjadi preseden baru yang kontraproduktif dalam penegakan hukum dan dapat disimpulkan bahwa penetapan tersebut melanggar prinsip hukum acara.

Kata kunci: penetapan, eksekusi, preseden baru.

\section{ABSTRACT}

Meulaboh District Court through its Decision Number 12/Pdt.G/2012/PN.Mbo in conjunction with Decision of the Banda Aceh District Court Number 50/Pdt/2014/ PN.Bna in conjunction with Supreme Court Decision Number $651 \mathrm{~K} / \mathrm{Pdt} / 2015$, sentenced PT KA to pay compensation for environmental damage due to forest fires. PT KA filed an extraordinary request for review which was then rejected through Court Decision Number 1 PK/Pdt/2017. By the time the Ministry of Environment and Forestry filed a writ of execution, the District Court of Meulaboh issued the Injuction Number 1/Pen/Pdt/ Eks/2017/PN.Mbo which ordered postponement of the execution and granted a legal protection to PT KA with the legal basis that PT KA was filing a new claim 
against the government. The main problem is whether the Injunction of Court Number 1/Pen/Pdt/Eks/2017/ PN.Mbo can delay a court decision that has a permanent legalforce. This research is conducted through normative juridical method based on literature sources by means of deductive reasoning in data verifying. The discussion in this research shows and explains that the injunction in the case of PT KA will cause legal uncertainty in judicial proceeding and is feared to create a new precedent that is counterproductive in law enforcement. The research concludes that the injunction has violated the main principle of procedural law.

Keywords: injunction, execution, new precedent.

\section{PENDAHULUAN}

\section{A. Latar Belakang}

Dalam praktik hukum acara perdata maupun hukum acara pidana, disebutkan bahwa kasasi merupakan bentuk upaya hukum terakhir yang dapat dilakukan oleh para pihak, bahkan upaya hukum luar biasa peninjauan kembali tidak dapat menghentikan eksekusi. Pemahaman bahwa putusan yang telah mempunyai kekuatan hukum tetap adalah putusan pengadilan yang diterima (tidak dilakukan upaya hukum), atau apabila dilakukan upaya hukum telah diputus oleh Mahkamah Agung melalui putusan kasasi.

Proses setelah putusan pengadilan berkekuatan hukum tetap atau setelah upaya hukum kasasi diputuskan Mahkamah Agung adalah eksekusi, ketentuan dalam hukum acara ini dibuat guna memberi kepastian hukum bagi pihak yang berperkara. Perkara PT KA, baik perdata maupun pidana pengadilan telah memutuskan melalui Putusan Nomor 12/Pdt.G/2012/PN.Mbo jo. Putusan Nomor 50/Pdt/2014/PN.Bna jo. Putusan Nomor $651 \mathrm{~K} / \mathrm{Pdt} / 2015$. Dalam perkara pidana melalui Putusan Nomor 131/Pid.B/2013/ PN.Mbo jo. Putusan Banding Nomor 201/ Pid/2014/PN.Bna jo. Putusan Nomor 1554 K/ Pid.Sus/2015.

Kementerian Lingkungan Hidup dan Kehutanan sudah mengirimkan Surat Nomor 103/ PSLH/GKM.1/11/2016 tertanggal 3 November
2016 kepada Pengadilan Negeri Meulaboh, yang pada intinya surat tersebut memohon pelaksanaan eksekusi berdasarkan putusan kasasi. Surat tersebut dibalas oleh Pengadilan Negeri Meulaboh melalui Surat Nomor 12/Pen. Pdt.Eks/2016/PN.Mbo yang isinya menyatakan penundaan eksekusi hingga turunnya putusan peninjauan kembali. Hal ini jelas-jelas melanggar hukum acara, bahwa peninjauan kembali tidak menunda eksekusi karena kasasi adalah upaya hukum terakhir, dan ironisnya pelanggaran hukum acara tersebut justru dilakukan oleh badan peradilan sendiri.

Kasus kebakaran hutan dan lahan PT KA, Kementerian Lingkungan Hidup dan Kehutanan kembali mengajukan surat teguran kepada Ketua Pengadilan Negeri Meulaboh melalui Surat Nomor S-24/PSLH/GKM.1/02/2017 untuk meminta dilaksanakan eksekusi terhadap PT KA, menindaklanjuti Putusan Nomor 1 PK/Pdt/2017 yang menolak permohonan peninjauan kembali PT KA.

Pertimbangan hukum dari penerbitan Penetapan Nomor 1/Pen/Pdt/Eks/2017/PN.Mbo adalah dikabulkannya permohonan perlindungan hukum PT KA, sehingga hal ini menjadi dasar pertimbangan majelis hakim dalam menyatakan eksekusi ditunda. Pertimbangan lain dalam penerbitan Penetapan Nomor 1/Pen/Pdt/ Eks/2017/PN.Mbo adalah PT KA melakukan 
gugatan terhadap pemerintah dengan gugatan baru setelah terbitnya putusan peninjauan kembali.

Pertimbangan majelis hakim tersebut menampakkan bahwa kekuasaan kehakiman justru menjadi alat untuk mengesampingkan kepastian hukum yang seharusnya menjadi tujuan penegakan hukum. Persoalan lainnya dari pertimbangan hukum majelis hakim pada penerbitan Penetapan Nomor 1/Pen/Pdt/Eks/2017/ PN.Mbo adalah penetapan tersebut bertentangan dengan hukum acara yang berlaku, karena dalam hal ini penetapan digunakan sebagai upaya hukum untuk menghindari eksekusi pada putusan pengadilan yang telah berkekuatan hukum tetap.

Menariknya perkara ini adalah menjadikan penetapan sebagai bentuk upaya hukum terhadap pelaksanaan eksekusi. Menerbitkan penetapan sesuai hukum acara adalah kewenangan pengadilan setempat, mengingat fenomena menggunakan penetapan pengadilan sebagai upaya hukum terhadap eksekusi ini baru terjadi dalam kasus PT KA ini. Penetapan pengadilan sebagaimana Penetapan Nomor 1/Pen/Pdt/ Eks/2017/PN.Mbo meskipun tidak dikenal di dalam hukum acara, tetapi juga tidak dilarang oleh Mahkamah Agung.

Mahkamah Agung secara limitatif menentukan jenis penetapan yang tidak diperbolehkan adalah hanya menetapkan status kepemilikan atas suatu benda baik bergerak maupun tidak bergerak, menetapkan status ahli waris, dan menetapkan bahwa suatu dokumen adalah sah (MA RI, 2009: 47). Artinya bahwa Penetapan Nomor 1/Pen/Pdt/Eks/2017/PN.Mbo tentang pemberian perlindungan hukum dan penundaan eksekusi tidak dilarang oleh Mahkamah Agung.
Penetapan dapat diajukan untuk masalah yang bersifat kepentingan sepihak saja (for benefit of one party only). Penetapan diterbitkan murni untuk menyelesaikan kepentingan pemohon tentang suatu permasalahan yang memerlukan suatu kepastian hukum, di mana yang dipermasalahkan tersebut tidak bersentuhan dengan hak dan kepentingan orang lain. Sifat penetapan harus tanpa sengketa dengan pihak lain (without disputes or differences with another party). Artinya tidak dibenarkan mengajukan permohonan tentang penyelesaian sengketa hak atau kepemilikan maupun penyerahan serta pembayaran sesuatu oleh orang lain atau pihak ketiga serta tidak ada pihak ketiga yang ditarik sebagai lawan atau bersifat ex-parte (Harahap, 2014: 29).

Penetapan Nomor 1/Pen/Pdt/Eks/2017/ PN.Mbo tentang pemberian perlindungan hukum dan penundaan eksekusi diterbitkan oleh Pengadilan Negeri Meulaboh, secara perdata PT KA diharuskan membayar ganti kerugian atas kebakaran hutan dan lahan dalam konsesi. Secara pidana PT KA dijatuhkan pidana denda hingga tahap peninjauan kembali sebagaimana telah diuraikan di atas, sehingga penetapan tersebut diterbitkan dengan tidak terpenuhi tiga unsur syarat penerbitan penetapan sebagaimana tersebut di atas.

Penetapan Nomor 1/Pen/Pdt/Eks/2017/ PN.Mbo diterbitkan sesuai permohonan PT KA sehingga pada unsur-unsur ini tidak dapat dipenuhi syarat penetapan untuk masalah yang bersifat kepentingan sepihak saja (for benefit of one party only). Secara praktis Kementerian Lingkungan Hidup dan Kehutanan sebagai pihak tentu berkepentingan untuk melakukan eksekusi atas putusan yang telah berkekuatan hukum. Lebih lanjut dalam hal ini $\mathrm{K}$ Kementerian 
Lingkungan Hidup dan Kehutanan sebagai pihak yang mewakili negara dan masyarakat untuk melawan pencemar lingkungan (poluter) yang hendak melakukan eksekusi untuk kepentingan rehabilitasi lingkungan hidup.

Penggunaan penetapan pengadilan untuk memberi perlindungan hukum atas upaya eksekusi yang akan dilakukan memang tidak diatur di dalam hukum acara, tetapi penetapan pengadilan tersebut juga bertentangan dengan hukum acara yaitu bahwa terhadap peninjauan kembali tidak menunda eksekusi. Artinya sebenarnya Pengadilan Negeri Meulaboh telah dua kali menyimpangi hukum acara, yaitu pada saat Kementerian Lingkungan Hidup dan Kehutanan mengirimkan Surat Nomor 103/ PSLH/GKM.1/11/2016 tertanggal 3 November 2016 yang meminta dilaksanakan eksekusi, namun Pengadilan Negeri Meulaboh menerbitkan Surat Nomor 12/Pen.pdt.Eks/2016/PN.Mbo yang isinya menolak eksekusi hingga terbit putusan peninjauan kembali.

Penyimpangan hukum acara yang kedua adalah ketika Pengadilan Negeri Meulaboh menerbitkan Penetapan Nomor 1/Pen/Pdt/ Eks/2017/PN.Mboyangmemberikan perlindungan hukum dan menunda eksekusi dikarenakan ada gugatan baru. Hal ini menyimpangi hukum acara yang berlaku, dan terkesan Pengadilan Negeri Meulaboh menyimpangi hukum acara untuk mengakomodir permohonan PT KA, akibatnya hingga saat ini eksekusi tidak dapat dilaksanakan. Ironisnya majelis hakim pada tingkat peninjauan kembali dalam pemeriksaan judex juris tidak menyatakan ada kekeliruan hakim kasasi pada Mahkamah Agung.

Penggunaan penetapan pengadilan sebagai bentuk upaya hukum baru ini akan menjadi kecenderungan bahkan pola baru dalam hukum acara untuk menghindari atau sebagai bentuk perlawanan terhadap proses eksekusi. Penggunaan penetapan pengadilan ini tentu mengandung sesat pikir dan melawan logika hukum acara. Jika penetapan pengadilan sebagaimana tersebut di atas digunakan sebagai bentuk upaya hukum pada proses eksekusi, dan terlebih lagi menjadi kecenderungan dan pola baru dalam peradilan Indonesia, maka akan kontradiktif dengan asas cepat, murah, dan biaya ringan serta peradilan sederhana. Artinya akan menambah tahapan baru dalam proses eksekusi. Dampaknya adalah aspek kepastian hukum terhadap putusan yang sudah berkekuatan hukum akan menjadi tersampingkan, sehingga proses peradilan tidak memberi kemanfaatan serta akan cenderung semakin transaksional.

Penetapan Pengadilan Nomor 1/Pen/ Pdt/Eks/2017/PN.Mbo yang memberikan perlindungan hukum dan menunda eksekusi menunjukkan bahwa lembaga peradilan sekalipun tidak dapat mengeksekusi putusan lembaga peradilan itu sendiri hingga tingkatan Mahkamah Agung. Persoalan ini akan menjadi preseden yang tidak baik bagi penegakan hukum karena hukum tidak lagi memiliki tujuan untuk mencapai kepastian, kemanfaatan, dan keadilan.

\section{B. Rumusan Masalah}

Apakah Penetapan Nomor 1/Pen/Pdt/ Eks/2017/PN.Mbo dapat menunda eksekusi atas putusan yang telah berkekuatan hukum tetap (inkracht)?

\section{Tujuan dan Kegunaan}

Tujuan tulisan ini adalah untuk meneliti dan mengkaji penggunaan penetapan pengadilan 
untuk penundaan eksekusi terhadap putusan yang telah berkekuatan hukum tetap. Tulisan ini diharapkan dapat memberikan kontribusi yang baik secara teoritis kepada disiplin ilmu hukum yang ditekuni oleh penulis maupun kepada para hakim untuk dapat dijadikan acuan dalam praktik, khususnya mengenai penetapan pengadilan.

\section{Tinjauan Pustaka}

\section{Teori dan Dasar Hukum Penetapan Pengadilan}

Dalam hal tidak ada perselisihan dan dalam hal pemohon tidak mohon putusan atau keadilan dari hakim, namun hanya mohon penetapan saja maka perkara disebut sebagai perkara permohonan. Jika ada dua pihak yang bersengketa dan para pihak mohon putusan maka disebut sebagai perkara gugatan (Hatta \&Yustanti, 2013: 4). Pemeriksaan untuk perkara permohonan sangat singkat, sedangkan dalam perkara gugatan dilakukan pemeriksaan dan pembuktian yang detail dan lengkap.

Khususnya dalam hukum acara perdata bahwa hakim harus mendengar kedua belah pihak (audi et alteram partem). Hakim tidak boleh mendengar keterangan dari salah satu pihak sebagai yang benar sehingga pihak lawan tidak diberi kesempatan mengeluarkan pendapat serta tidak didengar. Dalam hal memeriksa perkara perdata hakim harus mendengar dan mempertimbangkan keterangan kedua belah pihak yang bersengketa dan mengajukan alat bukti harus di depan sidang yang dihadiri kedua belah pihak (Chandera \& Tjandra, 2012: 4).

Penetapan adalah putusan yang berisi diktum penyelesaian permohonan yang dituangkan dalam bentuk ketetapan pengadilan. Sifat dari penetapan pengadilan adalah sebagai berikut: a. Diktum bersifat deklaratoir, yakni hanya berisi penegasan pernyataan atau deklarasi hukum tentang hal yang diminta;

b. Pada penetapan pengadilan tidak boleh mencantumkan diktum condemnatoir (yang mengandung hukuman) terhadap siapapun;

c. Pada penetapan diktum tidak dapat memuat amar konstitutif, yaitu yang menciptakan suatu keadaan baru (Harahap, 2014: 40).

Penetapan pengadilan dapat dipersamakan dengan putusan pengadilan pada tingkat pertama dan terakhir. Sesuai dengan doktrin dan praktik yang berlaku bahwa penetapan yang dijatuhkan dalam perkara yang berbentuk permohonan atau voluntair pada umumnya dapat dipersamakan dengan putusan pada tingkat pertama dan terakhir.

Suatu penetapan pengadilan dapat dikeluarkan berdasarkan adanya permohonan atau gugatan voluntair yang ditandatangani oleh pemohon (baik perorangan maupun badan hukum) atau kuasanya yang ditujukan kepada ketua pengadilan negeri. Istilah permohonan atau gugatan voluntair ini dapat dilihat dalam penjelasan Pasal 2 ayat (1) Undang-Undang Nomor 14 Tahun 1970 tentang KetentuanKetentuan Pokok Kekuasaan Kehakiman yang meskipun tidak diatur lagi dalam Undang-Undang Nomor 4 Tahun 2004, dan terakhir diperbaharui dengan Undang-Undang Nomor 48 Tahun 2009 tentang Kekuasaan Kehakiman sebagai pengganti Undang-Undang Nomor 14 Tahun 1970.

Ketentuan sebagaimana dalam penjelasan Pasal 2 ayat (1) Undang-Undang Nomor 14 Tahun 1970 tentang Ketentuan-Ketentuan Pokok Kekuasaan Kehakiman masih dianggap relevan dan merupakan penegasan di samping kewenangan badan peradilan terhadap perkara gugatan, tetapi termasuk juga pada perkara 
voluntair untuk meminta penetapan yang hanya melibatkan satu pihak saja. Perkara permohonan adalah termasuk pada pengertian yurisdiksi voluntair dan berdasarkan permohonan yang diajukan oleh pemohon maka hakim memberikan suatu penetapan (Elmiyah \& Sujadi, 2005: 327).

Mengacu pada yurisprudensi Mahkamah Agung Nomor 3139/K/Pdt/1984, dikatakan bahwa tugas pokok pengadilan adalah memeriksa dan memutus perkara yang bersifat sengketa. Selain itu pengadilan juga memeriksa voluntair jurisdiction, namun kewenangan itu terbatas pada hal-hal yang ditegaskan oleh peraturan perundang-undangan. Yurisdiksi penetapan pengadilan memang diperluas pada hal-hal yang ada urgensinya itupun dengan syarat jangan sampai memutus perkara voluntair yang mengandung sengketa (Elmiyah \& Sujadi, 2005: 327).

Penetapan pengadilan hanya dapat diterbitkan untuk hal-hal yang sangat bersifat limitatif dengan syarat ex-parte atau sepihak dalam keadaan sangat terbatas dan sangat eksepsional pada hal tertentu saja dan hanya boleh terhadap masalah yang disebut dan ditentukan oleh undang-undang yang menegaskan bahwa masalah yang bersangkutan dapat atau boleh diselesaikan secara voluntair dalam bentuk permohonan untuk mendapat penetapan (Elmiyah \& Sujadi, 2005: 327-328).

\section{Peradilan Untuk Mewujudkan Kepastian Hukum}

Kekuasaan kehakiman merupakan kekuasaanyangmerdekauntukmenyelenggarakan peradilan guna menegakkan hukum dan keadilan. Penegasan tersebut terdapat juga dalam UndangUndang Kekuasaan Kehakiman yang mengatur bahwa kekuasaan kehakiman adalah kekuasaan negara yang merdeka untuk menyelenggarakan peradilan guna menegakkan hukum dan keadilan berdasarkan Pancasila demi terselenggaranya negara hukum Republik Indonesia. Fakta hukum pada umumnya menunjukkan adanya ketidakpercayaan masyarakat pada kekuasaan kehakiman dikarenakan belum mencerminkan kepastian hukum (Wantu, 2012: 480).

Kanter mengilustrasikan "jika anda tidak mau kehilangan kerbau demi menyelamatkan kambing janganlah anda memprosesnya ke pengadilan" (Kanter, 2013: 161). Pernyataan Kanter tersebut menunjukkan ketidakpercayaan masyarakat terhadap institusi peradilan. Hakim sebagai salah satu pejabat kekuasaan kehakiman yang melaksanakan proses peradilan harus memiliki tanggung jawab terhadap putusan/ penetapan pengadilan yang dibuatnya. Putusan/ penetapan yang dibuat oleh hakim di pengadilan idealnya tidak menimbulkan masalah baru di masyarakat, artinya kualitas putusan/penetapan berpengaruh pada kewibawaan dan kredibilitas lembaga peradilan itu sendiri.

Hakim dalam menyelesaikan persoalan di pengadilan mempunyai tugas untuk menemukan hukum yang tepat, hakim dalam menemukan hukum tidak cukup hanya mencari undangundang saja, sebab ada kemungkinan undangundang tidak mengatur secara jelas, sehingga hakim harus menggali nilai yang hidup dalam masyarakat. Idealnya dalam upaya mencapai kepastian hukum dalam membuat suatu penetapan harus sesuai dengan tujuan dasar pengadilan sehingga mengandung kepastian hukum (Wantu, 2012: 483).

Penetapan pengadilan yang dapat memberikan kepastian hukum haruslah bersifat: (1) melakukan solusi autoritatif; (2) efisiensi, 
artinya dalam prosesnya harus cepat, murah, dan biaya ringan; (3) sesuai dengan peraturan perundang-undangan; (4) mengandung aspek stabilitas, yaitu dapat memberikan rasa tertib dan rasa aman dalam masyarakat; dan (5) mengadung equality, artinya mengandung kesamaan bagi siapa saja (Wantu, 2012: 483).

Kepastian hukum yang dituangkan dalam penetapan hakimmerupakan hasilyang didasarkan pada fakta-fakta persidangan yang relevan secara yuridis serta menggunakan hati nurani. Dalam hal adanya permohonan penetapan, hakim selalu dituntut untuk selalu dapat menafsirkan makna peraturan perundangan dalam situasi konkret yang dimohonkan kepadanya. Hakim dapat mengkonstruksi kasus yang diadili secara utuh dan objektif sehingga dapat terpenuhi kepastian hukum.

\section{Pelaksanaan dan Penundaan Eksekusi}

Pengertian eksekusi adalah merupakan pelaksanaan putusan pengadilan yang telah mempunyai kekuatan hukum tetap. Prinsipnya eksekusi dijalankan karena pihak yang kalah tidak menjalankan putusan pengadilan secara sukarela. Eksekusi dijalankan dengan mengacu pada Pasal 195 dan 196 HIR atau Pasal 207 dan 208 RBG. Dalam pengertian lain eksekusi adalah menjalankan putusan pengadilan yang sudah berkekuatan hukum tetap.

Putusan yang dieksekusi adalah putusan yang mengandung perintah kepada salah satu pihak untuk membayar sejumlah uang atau melaksanakan perintah hakim lainnya, sedangkan pihak yang kalah tersebut tidak mau melaksanakan putusan secara sukarela sehingga memerlukan upaya paksa dari pengadilan untuk melaksanakannya (Haris, 2016: 313).
Selain mengacu pada HIR dan RBG, prosedur eksekusi juga diatur dalam UndangUndang Nomor 48 Tahun 2009 tentang Kekuasaan Kehakiman, yaitu Pasal 54 dan 55 yang secara teknis dijewantahkan melalui Peraturan Mahkamah Agung Nomor 1 Tahun 1980, dalam kaitannya kasasi merupakan upaya hukum yang terakhir dan upaya hukum peninjauan kembali tidak menghalangi eksekusi.

Prinsip eksekusi dilaksanakan pada putusan pengadilan yang telah berkekuatan hukum tetap, karena putusan pengadilan yang telah berkekuatan hukum tetap tidak lagi terbuka kemungkinan untuk dibatalkan, dalam hal ini karena upaya hukum luar biasa peninjauan kembali adalah ditujukan pada putusan pengadilan yang telah berkekuatan hukum tetap (Bachir, 2015: 22).

Eksekusi menggunakan irah-irah "Demi Ketuhanan Berdasarkan Ketuhanan Yang Maha Esa." Hal ini untuk menunjukkan bahwa eksekusi wajib dijalankan demi kepastian hukum dan keadilan para pihak melalui realisasi putusan yang telah berkekuatan hukum tetap, namun pelaksanaan eksekusi tidak serta merta dapat dilaksanakan jika terdapat alasan yang dapat menunda eksekusi.

Alasan yang dapat menunda eksekusi putusan pengadilan yang telah berkekuatan hukum tetap adalah sebagai berikut:
a. Para pihak telah membuat kesepakatan damai.
b. Alasan Perikemanusiaan yang dapat diterima oleh pengadilan.
c. Masih terdapat perlawanan dari pihak ketiga.
d. $\quad$ Barang yang menjadi objek eksekusi masih dalam perkara lain (Makaro, 2014: 235-239). 
Alasan penundaan eksekusi telah ditentukan secara limitatif, sehingga bila pelaksanaan eksekusi ditunda karena sebab di luar dari yang telah ditentukan, maka hal ini akan merusak citra lembaga peradilan dan menurunkan kepercayaan masyarakat terhadap hukum, karena dipandang hukum dalam hal ini lembaga peradilan tidak dapat memberikan kepastian hukum.

\section{METODE}

Metode yang digunakan dalam tulisan ini adalah metode penelitian yuridis normatif dengan fokus melakukan kajian yuridis terhadap penggunaan penetapan pengadilan untuk menunda eksekusi serta memberi perlindungan hukum pada salah satu pihak. Untuk mencapai maksud di atas digunakan studi kepustakaan, yaitu menggunakan bahan hukum untuk menjawab rumusan masalah. Dalam hal ini digunakan putusan pengadilan, peraturan perundangan, doktrin serta literatur yang mendukung yang terbagi menjadi bahan hukum primer, sekunder maupun tersier.

Tulisan ini menggunakan pendekatan penelitian hukum normatif dengan melakukan abstraksi terhadap proses deduksi dari norma hukum positifyang berlaku, yaitu meneliti hukum sebagai norma positif dengan menggunakan cara berpikir deduktif dan berdasarkan pada kebenaran koheren, di mana kebenaran dalam penelitian ini sudah dinyatakan kredibel tanpa harus melalui proses pengujian atau verifikasi.

Data yang dimaksudkan dalam penelitian ini adalah bahan-bahan atau fakta-fakta atau bisa juga diartikan sebagai sumber informasi. Sedangkan bahan hukum yang dimaksudkan dalam penelitian ini terdiri dari bahan hukum primer dan bahan hukum sekunder. Bahan hukum primer adalah merupakan bahan hukum yang bersifat autoritatif artinya mempunyai otoritas peraturan perundangan, risalah atau catatan resmi, dan putusan pengadilan. Sedangkan yang dimaksud bahan hukum sekunder adalah bukubuku (pendapat ahli), jurnal, dan segala sesuatu yang dapat memberikan petunjuk bagi peneliti.

Data yang diperoleh dianalisis sehingga dapat ditemukan alasan yang rasional mengenai rumusan permasalahan dan analisisnya. Dari hasil pengolahan tersebut dianalisis dan kemudian dilakukan pembahasan dan ditarik kesimpulan atas penggunaan penetapan untuk menunda eksekusi atas putusan yang telah berkekuatan hukum tetap.

\section{HASIL DAN PEMBAHASAN}

Penetapan Nomor 1/Pen/Pdt/Eks/2017/ PN.Mbo yang memberikan perlindungan hukum dan menunda eksekusi diterbitkan dalam rangka eksekusi Putusan Nomor 12/Pdt.G/2012/ PN.Mbo jo. Putusan Nomor 50/Pdt/2014/ PN.Bna jo. Putusan Nomor 651 K/Pdt/2015 yang menjatuhkan putusan ganti rugi kepada PT KA. Dalam perkara pidana melalui Putusan Nomor 131/Pid.B/2013/PN.Mbo jo. Putusan Banding Nomor 201/Pid/2014/PN.Bna jo. Putusan Nomor $1554 \mathrm{~K} / \mathrm{Pid}$.Sus/2015 yang menjatuhkan pidana denda kepada PT KA, bahkan dalam Putusan Peninjauan Kembali Nomor 1 PK/Pdt/2017 juga menolak permohonan peninjauan kembali PT KA.

Penetapan Nomor 1/Pen/Pdt/Eks/2017/ PN.Mbo merupakan bentuk upaya hukum PT KA guna menghindari eksekusi atas putusan yang telah berkekuatan hukum tetap. Memang belum diatur secara eksplisit jika pihak PT KA mengajukan permohonan penetapan untuk 
memberikan perlindungan hukum dan menunda eksekusi. Penetapan Nomor 1/Pen/Pdt/Eks/2017/ PN.Mbo tidak lazim diterbitkan oleh pengadilan sebagai bentuk permohonan karena terdapat unsur sengketa dan kepentingan pihak lain di dalamnya (bukan ex-parte). Melihat histori perkara ini lebih kepada bentuk upaya hukum lanjutan dari termohon eksekusi. Persoalannya adalah Penetapan Nomor 1/Pen/Pdt/Eks/2017/ PN.Mbo tidak dikenal dalam hukum acara serta menyimpangi hukum acara itu sendiri.

Merunut pada Putusan Nomor 12/ Pdt.G/2012/PN.Mbo jo. Putusan Nomor 50/ Pdt/2014/PN.Bna jo. Putusan Nomor 651 K/ $\mathrm{Pdt} / 2015$ yang menjatuhkan putusan ganti rugi kepada PT KA yang dikuatkan Putusan Nomor $1 \mathrm{PK} / \mathrm{Pdt} / 2017$ juga menolak permohonan peninjauan kembali. PT KA dianggap harus bertanggung jawab secara perdata atas dasar perbuatan melawan hukum. Analisis tanggung jawab perdata PT KA kepada pemerintah terhadap pembukaan lahan dengan cara membakar berdasarkan Putusan Nomor 12/Pdt.G/2012/ PN.Mbo adalah mengacu pada tanggung jawab hukum sebagaimana diatur dalam Pasal 1365 dan 1367 Kitab Undang-Undang Hukum Perdata (Koespratama et al., 2016: 9).

Pasal 1365 Kitab Undang-Undang Hukum Perdata yaitu terkait perbuatan melawan hukum, bahwa setiap perbuatan melawan hukum yang menimbulkan kerugian terhadap pihak lain mewajibkan pihak yang karena perbuatannya menimbulkan kerugian untuk mengganti kerugian itu. Jika Penetapan Nomor 1/Pen/Pdt/Eks/2017/ PN.Mbo diterbitkan sebagai satu rangkaian dengan putusan tersebut, maka dalam hal permohonan penetapan yang diajukan termohon eksekusi mengandung sengketa dan kepentingan pihak lain.
Perbuatan melawan hukum yang dilakukan termohon eksekusi sesuai Putusan Nomor 651 $\mathrm{K} / \mathrm{Pdt} / 2015$ yang menjatuhkan putusan ganti rugi kepada termohon eksekusi, secara perdata bahwa seorang pencemar wajib membayar ganti rugi berdasarkan perbuatan melawan hukum yang dilakukannya sebagaimana dikenal dengan prinsip polluter-pays principle.

Mishan dalam the cost of economic growth pada tahun enam puluhan memperkenalkan polluter-pays principle (prinsip pencemar harus membayar) yang menyebutkan bahwa pencemar semata-mata adalah seseorang/badan yang berbuat pencemaran yang seharusnya dihindarinya (Muhdar, 2009: 67).

Putusan Nomor $651 \mathrm{~K} / \mathrm{Pdt} / 2015$ yang menjatuhkan putusan ganti rugi kepada termohon eksekusi menerapkan asas in dubio pro natura, yaitu bahwa dalam penyelesaian perkara lingkungan hidup baik secara perdata, pidana, dan administrasi memang harus menggunakan asas in dubio pro natura yang telah dimanifestasikan dalam Pasal 2 Undang-Undang Nomor 32 Tahun 2009 tentang Perlindungan dan Pengelolaan Lingkungan Hidup.

Pasal 2 Undang-Undang Nomor 32 Tahun 2009 tentang Perlindungan dan Pengelolaan Lingkungan Hidup mengatur tentang kehatihatian, keadilan lingkungan, dan keanekaragaman hayati, oleh sebab itu dapat dipahami jika keberatan PT KA sebagai pemohon kasasi ditolak oleh majelis kasasi dan Mahkamah Agung memutus termohon eksekusi telah melakukan perbuatan melawan hukum dan menghukum ganti rugi berdasarkan kerugian ekologis.

Kerugian yang dimaksud terdiri dari kerugian ekologis penyimpanan air, pengendalian erosi, pembentukan tanah, keanekaragaman 
hayati, sumber daya genetik, pelepasan karbon, dan kerugian ekonomi oleh negara yang terdiri dari hilangnya manfaat pemakaian dan biaya pemulihan yang harus dikeluarkan oleh negara. Melalui Putusan Nomor $651 \mathrm{~K} / \mathrm{Pdt} / 2015$ menyatakan bahwa judex factie pada Putusan Nomor 12/ Pdt.G/2012/PN.Mbo jo. Putusan Pengadilan Nomor 50/Pdt/2014/PN.Bna tidak bertentangan dengan hukum dan atau undang-undang sehingga putusan berkekuatan hukum tetap.

Termohon eksekusi diputuskan telah melakukan perbuatan melawan hukum sehingga diputuskan harus mengganti kerugian. Sesuai yurisprudensi Mahkamah Agung Nomor 610/K/ Slip/1968, bahwa meskipun tuntutan ganti kerugian jumlahnya dianggap tidak pantas sedang penggugat menuntut sejumlah itu, maka hakim berwenang untuk menetapkan berapa yang seharusnya dibayar.

Mahkamah Agung mempedomani Putusan Hoge Raad tanggal 24 Mei 1918 yang menyatakan bahwa pengembalian pada keadaan semula adalah keputusan yang paling tepat (Koespratama et al., 2016: 13), maka dalam hal ini Mahkamah Agung menguatkan putusan ganti kerugian sebesar Rp114.303.419.000,-- sebagai ganti rugi materiel atas tindakan melawan hukum, ganti rugi tersebut dihitung untuk mengembalikan keadaan seperti semula berdasarkan kerugian ekologis yang terdiri dari kerugian ekologis penyimpanan air, pengendalian erosi, pembentukan tanah, keanekaragaman hayati, sumber daya genetik, pelepasan karbon, dan kerugian ekonomi oleh negara yang terdiri dari hilangnya manfaat pemakaian dan biaya pemulihan yang harus dikeluarkan oleh negara.

Termohon eksekusi juga diharuskan melakukan tindakan pemulihan lingkungan terhadap 1.000 ha lahan gambut yang terbakar sebesar Rp251.765.250.000,- sehingga lahan gambut yang terbakar tersebut dapat difungsikan kembali. Putusan perdata tersebut sama dengan putusan kasasi dalam perkara pidana melalui Putusan Nomor 131/Pid.B/2013/PN.Mbo jo. Putusan Nomor 201/Pid/2014/PN.Bna jo. Putusan Nomor 1554 K/Pid.Sus/2015 menghukum termohon eksekusi untuk membayar denda karena kebakaran hutan dan lahan yang disebabkan karena kelalaian termohon eksekusi menyebabkan percepatan pemanasan global dan mengurangi zat karbon yang sangat dibutuhkan untuk kehidupan manusia.

Putusan Nomor 12/Pdt.G/2012/PN.Mbo jo. Putusan Nomor 50/Pdt/2014/PN.Bna jo. Putusan Nomor 651 K/Pdt/2015 menghukum PT KA untuk membayar ganti rugi atas kerusakan lingkungan yang ditimbulkan sebagai akibat dari kebakaran hutan. Putusan Nomor 1 PK/ Pdt/2017 yang dimohonkan PT KA juga menolak permohonan peninjauan kembali PT KA. Bahkan dalam perkara yang sama pengadilan pidana juga telah menjatuhkan putusan hingga Mahkamah Agung melalui Putusan Nomor 131/Pid.B/2013/ PN.Mbo jo. Putusan Nomor 201/Pid/2014/ PN.Bna jo. Putusan Nomor 1554 K/Pid.Sus/2015 yang menjatuhkan pidana terhadap PT KA seluruhnya adalah menggunakan pendekatan keadilan korektif.

Keadilan korektif dapat dipahami dari ratio decidendi (pertimbangan hukum) hakim untuk sampai pada putusan yang digambarkan oleh Goodheart dalam Marzuki sebagai fakta materiil (Marzuki, 2017: 39). Fakta tersebut berupa orang, benda, tempat, waktu, dan biaya sehingga dapat disimpulkan secara preskriptif mengingat ratio decidendi (pertimbangan hukum). Keadilan korektif merupakan bentuk 
keadilan yang ditujukan sebagai upaya pemberian sanksi, pembebanan kewajiban pemulihan atau kewajiban melakukan kompensasi bagi mereka yang menimbulkan kerugian bagi pihak lain. Dalam konteks ini, mereka yang menimbulkan kerugian berarti memikul tanggung jawab untuk mengembalikan dampak akibat kerugian tersebut (Wibisana, 2017: 297).

Keadilan korektif menginginkan agar mereka yang menyebabkan terjadinya kerugian untuk memperbaiki kerugian yang terjadi tersebut. Adler \& Wilkinson dalam Hudoyo et al. (2017: 202), menyatakan bahwa keadilan korektif adalah dasar penerapan polluter-pays principle (prinsip pencemar harus membayar) yang secara lex specialis diatur dalam penjelasan Pasal 87 ayat (1) Undang-Undang Nomor 32 Tahun 2009 tentang Perlindungan dan Pengelolaan Lingkungan Hidup menyatakan bahwa pasal tersebut merupakan realisasi pencemar harus membayar.

Pasal 87 merupakan pasal tentang pertanggungjawaban perdata berdasarkan perbuatan melawan hukum, maka UndangUndang Nomor 32 Tahun 2009 menggunakan tafsir pertanggungjawaban berdasarkan kesalahan (liability based on fault) (Wibisana, 2017: 298). Dapat dipahami konstruksi hukumnya mengingat untuk menyatakan perbuatan melawan hukum perlu dibuktikan kesalahan untuk menuntut tanggung jawab, maka kasus PT KA diadili baik secara perdata untuk menuntut pertanggungjawaban perdata berdasarkan perbuatan melawan hukum, sedangkan pidana untuk membuktikan secara materiel pertanggungjawaban berdasarkan kesalahan (liability based on fault).

Berdasarkan uraian di atas dapat dipahami dengan terang benderang dan jelas bahwa perkara tersebut tidak hanya menyangkut kepentingan satu pihak saja (ex parte) tetapi ada kepentingan pihak lain yang secara nyata merupakan kepentingan bangsa, negara, dan masyarakat. Terbitnya Penetapan Nomor 1/Pen/Pdt/Eks/2017/ PN.Mbo untuk memberi perlindungan hukum kepada termohon eksekusi dan menunda proses eksekusi pasca Putusan Nomor 1 PK/Pdt/2017 yang menolak permohonan peninjauan kembali PT KA merupakan suatu penyimpangan dalam hukum formal maupun materiel.

Penyimpangan hukum sudah terjadi pada saat Kementerian Lingkungan Hidup dan Kehutanan mengirimkan Surat Nomor 103/ PSLH/GKM.1/11/2016 tertanggal 3 November 2016 yang meminta dilaksanakan eksekusi namun Pengadilan Negeri Meulaboh menerbitkan Surat Nomor 12/Pen.Pdt.Eks/2016/PN-Mbo yang isi menolak eksekusi hingga terbit putusan peninjauan kembali, hal ini sudah bertentangan dengan hukum acara yang menyatakan upaya hukum peninjauan kembali tidak dapat menunda eksekusi. Selanjutnya penyimpangan hukum acara yang kedua adalah ketika Pengadilan Negeri Meulaboh menerbitkan Penetapan Nomor 1/Pen/Pdt/Eks/2017/PN.Mbo yang memberikan perlindungan hukum dan menunda eksekusi dikarenakan ada gugatan baru, hal ini lebih aneh dan sangat bertentangan dengan logika kepastian hukum sehingga dapat terlihat Penetapan Nomor 1/Pen/Pdt/Eks/2017/PN.Mbo adalah sangat tidak netral.

Yurisprudensi Mahkamah Agung Nomor 5/Pen/Sep/1975 yang menyatakan batal demi hukum Penetapan Pengadilan Negeri Jakarta Pusat Nomor 272/1972.P dan Nomor 273/1972.P dalam kasus FPC menyatakan bahwa Mahkamah Agung sebagai pengawas tertinggi jalannya peradilan membatalkan penetapan pengadilan 
negeri dikarenakan bahwa kedua penetapan tersebut bersifat prosesuil yang didasarkan atas suatu gugatan yang mana pihak yang terkena dampak maupun dikutip dalam ketetapan tersebut seharusnya diberi kesempatan untuk membela diri dan didengar hakim.

Sebagai pembanding terkait penetapan pengadilan negeri ini adalah yurisprudensi Mahkamah Agung Nomor 02 Pen/Pdt/2003 yang membatalkan Penetapan Pengadilan Negeri Jakarta Pusat Nomor 149/Pdt/P/PN Jkt.Pst/2003, Nomor 150/Pdt/P/PN Jkt.Pst/2003, dan Nomor 151/Pdt/P/ PN Jkt.Pst/2003 dengan alasan pembatalan bahwa setiap hal terkait eksekusi harus ditempuh melalui gugatan dengan memberi kesempatan kepada semua pihak untuk didengarkan keterangannya oleh hakim sehinggar perkara sebagaimana dimaksud bukan termasuk yurisdiksi gugatan voluntaire yang diselesaikan dengan penetapan.

Penetapan Nomor 1/Pen/Pdt/Eks/2017/ PN.Mbo bukan saja menyimpangi hukum formal dan materiel, tetapijuga kontra-produktif terhadap upaya pengadilan mewujudkan kepastian hukum. Tugas utama hakim adalah menemukan hukum melalui penyelesaian pemeriksaan perkara baik dengan putusan maupun penetapan. Penemuan hukum baik melalui putusan maupun penetapan tersebut dengan cara melihat peraturan perundangundangan ataupun melakukan penemuan hukum lainnya dalam rangka mewujudkan kepastian hukum. Dapat dikatakan bahwa pada hakikatnya kepastian hukum merupakan suatu keadaan di mana perilaku manusia, baik individu kelompok maupun organisasi berada di dalam koridor yang sudah digariskan oleh hukum (Afriana \& Fakhriah, 2016: 284).

Dalam permohonan penetapan yang terlibat dalam permohonan tersebut hanyalah sepihak, yang mana pihak inilah yang disebut pemohon (ex-parte). Adapun sifat ex-parte adalah sebagaimana dimaksud adalah hanya mendengar keterangan dari pemohon atau kuasanya sehubungan dengan permohonan serta memeriksa bukti dan saksi yang diajukan oleh pemohon serta tidak ada tahapan replik-duplik serta kesimpulan.

Pemeriksaan permohonan penetapan pengadilan yang diajukan oleh pemohon harus dilandasi bukti dan pembuktian tersebut dibebankan kepada pemohon untuk dijadikan pertimbangan hakim dalam memeriksa dan memberikan penetapan yang mana bukti sebagaimana dimaksud harus sesuai Pasal 1866 b Kitab Undang-Undang Hukum Perdata dan Pasal 164 HIR/284 RBG. Setelah hakim memeriksa permohonan berikut bukti-bukti yang telah diajukan pemohon dan alasan-alasan pemohon dalam mengajukan permohonan telah memenuhi ketentuan, maka dengan memuat pertimbangan hukum dalam diktum, maka penyelesaian permohonan tersebut dapat dituangkan dalam penetapan (Elmiyah \& Sujadi, 2005: 333).

Bahwa penetapan yang dikeluarkan atau ditetapkan oleh pengadilan merupakan produk yang diterbitkan oleh hakim dalam menyelesaikan masalah yang diajukan kepadanya sehingga dengan sendirinya penetapan tersebut merupakan akta otentik sebagaimana dimaksud dalam Pasal 1868 huruf $\mathrm{b}$ Kitab Undang-Undang Hukum Perdata (Setiawan, 2012: 399).

Apabila selama proses permohonan penetapan, pihak yang merasa dirugikan dapat mengajukan perlawanan, dalam hal ini perlawanan bermanfaat untuk menghindari penetapan yang keliru sehingga bagi pihak yang dirugikan dapat mengajukan perlawanan (derden verzet) 
yang bersifat quasi derden verset selama proses permohonan penetapan berlangsung. Dalam hal ini pelawan meminta agar permohonan ditolak serta perkara diselesaikan secara contradictoir (Elmiyah \& Sujadi, 2005: 335).

Terhadap penetapan pengadilan bersifat yang pertama dan terakhir artinya tidak dapat diajukan banding sehingga sesuai Pasal 43 ayat (1) Undang-Undang Nomor 14 Tahun 1985 tentang Mahkamah Agung sebagaimana diubah dengan Undang-Undang Nomor 5 Tahun 2004 tentang Perubahan Atas Undang-Undang Nomor 14 Tahun 1985 tentang Mahkamah Agung, maka upaya hukum terhadap penetapan pengadilan adalah kasasi.

Yurisprudensi Mahkamah Agung Nomor $3302 \mathrm{~K} / \mathrm{Pdt} / 1196$ tertanggal 28 Mei 1998 Mahkamah Agung menyatakan bahwa tuntutan pembatalan penetapan seharusnya diajukan kasasi ke Mahkamah Agung sesuai dengan ketentuan Pasal 30 Undang-Undang Nomor 14 Tahun 1985 yang menyatakan Mahkamah Agung dalam tingkat kasasi berwenang membatalkan putusan atau penetapan pengadilan dari semua lingkungan peradilan karena tidak berwenang atau melampaui batas wewenang, salah menerapkan atau melanggar hukum yang berlaku serta lalai memenuhi syarat yang diwajibkan oleh peraturan perundangan.

Sesuai Pasal 43 ayat (1) permohonan kasasi terhadap penetapan hanya dapat diajukan jika pemohon terhadap perkaranya telah menggunakan upaya hukum banding kecuali ditentukan lain dan permohonan kasasi hanya dapat diajukan satu kali, dalam hal penetapan diatur bahwa bersifat pertama dan terakhir sehingga upaya hukum yang dapat dilakukan adalah kasasi. Jika kita memahami Penetapan Nomor 1/Pen/
Pdt/Eks/2017/PN.Mbo sebagai hukum konkret, maka sebagai refleksi pada hakikatnya hukum mengandung ide atau konsep mengenai keadilan, kepastian, dan kemanfaatan.

$$
\text { Raharjo merumuskan penegakan }
$$
hukum dapat diartikan sebagai upaya untuk mewujudkan hukum dalam kenyataan, rumusan tersebut tersirat dalam definisi hukum menurut Kusumaatmadja (Afriana \& Fakhriah, 2016: 276) yang mendefinisikan hukum sebagai keseluruhan asas dan kaidah yang mengatur kehidupan masyarakat termasuk di dalamnya lembagalembaga dan proses-proses untuk mewujudkan hukum tersebut dalam kenyataan.

Soekanto (Fuady, 2012: 39) mendefinisikan penegakan hukum sebagai kegiatan menyelarasikan nilai-nilai yang terjabarkan dalam kaidah-kaidah konkret yang mengejawantahkan sikap tindak sebagai rangkaian penjabaran nilai tahap akhir untuk mencipatakan, memelihara, dan mempertahankan kedamaian pergaulan hidup.

Kenyataannya saat ini refleksi proses peradilan kita adalah sebagaimana disampaikan Harkrisnowo (Fuady, 2012: 40), bahwa kondisi hukum di Indonesia saat ini ditengarai mendekati titik nadir, telah mendapat sorotan yang luar biasa dari komunitas dalam negeri maupun internasional, proses penegakan hukum acap kali diskriminatif, inkonsisten, dan mengedepankan kepentingan kelompok.

Putusan Nomor 19/G/2011/PTUN-BNA perkara antara WALHI melawan PT KA jelas mendefinisikan bahwa yang dimaksud kepastian hukum adalah asas dalam negara hukum yang mengutamakan landasan peraturan perundangan, kepatutan, dan keadilan dalam setiap ketetapan eksekutif. 
Sebagai pembanding keadilan korektif, penulis mencoba menggunakan pendekatan keadilan prosedural dalam memahami Penetapan Nomor 1/Pen/Pdt/Eks/2017/PN.Mbo Keadilan prosedural ini memfokuskan pada proses pengambilan keputusan yang adil dan bukan pada hasil pengambilan keputusan tersebut, sehingga keadilan ini menuntut model pengambilan keputusan yang lebih deliberatif, perlindungan kepada pihak yang dirugikan serta adanya akses yang setara pada proses pengambilan keputusan (Wibisana, 2017: 299).

Rawls (Anshori, 2015: 50) memandang keadilan prosedural sebagai berikut "first, each person is to have an equal right to the most extensive basic liberty compatible with similar liberty for others, second social and economics inequalities are to be range so that they are both (a) reasonable expected to be to everyone's advantage, and (b) attached to positions and offices open to all."

Penetapan Nomor 1/Pen/Pdt/Eks/2017/ PN.Mbo membawa dampak besar, hal ini dikarenakan pemohon eksekusi dalam hal ini Kementerian Lingkungan Hidup dan Kehutanan mewakili masyarakat dan negara dihadapkan pada pilihan yang sama-sama merugikan, yaitu melakukan upaya hukum terhadap Penetapan Nomor 1/Pen/Pdt/Eks/2017/PN.Mbo sesuai mekanisme yang telah diuraikan pada bagian sebelumnya, atau menghadapi gugatan baru dari termohon eksekusi.

Baik melakukan upaya hukum terhadap Penetapan Nomor 1/Pen/Pdt/Eks/2017/PN.Mbo maupun menghadapi gugatan baru dari termohon eksekusi, keduanya sama-sama merugikan pemohon eksekusi dan keduanya tetap akan menjadi preseden yang buruk bagi penegakan hukum di Indonesia, mengingat perkara yang telah inkracht tidak dapat dieksekusi dan ditangguhkan eksekusinya oleh lembaga peradilan melalui penetapan yang hanya mempertimbangkan permohonan salah satu pihak, padahal ini merupakan perkara sengketa.

Dalam hal disimpanginya asas hukum dan peraturan hukum konkret pada penerbitan Penetapan Nomor 1/Pen/Pdt/Eks/2017/ PN.Mbo seharusnya Mahkamah Agung dapat melakukan koreksi atas penetapan pengadilan negeri seperti beberapa yurisprudensi yang telah diuraikan di atas, namun penegakan hukum yang penuh penyimpangan akan berdampak bagi terabaikannya kepastian hukum mengingat jika dilakukan upaya atas Penetapan Nomor 1/ Pen/Pdt/Eks/2017/PN.Mbo memerlukan energi, waktu, dan biaya terhadap perkara yang telah diputus inkracht sampai dengan peninjauan kembali dapat dimentahkan dengan penetapan pengadilan negeri.

Perlu menjadi catatan bahwa jika diajukan gugatan baru dengan objek yang sudah pernah diadili dalam persidangan sebelumnya, maka seharusnya pengadilan menolak gugatan tersebut karena menyimpangi asas dasar ilmu hukum nebis in idem, namun dalam hal kasus PT KA jika objek perkara yang diadili berbeda maka seharusnya gugatan baru tidak menghalangi eksekusi. Menurut Kusumaatmadja (Fuady, 2012: 42) dalam tahap penerapannya asas-asas hukum itu dimantapkan melalui produk pengadilan, di sini peran Mahkamah Agung sebagai badan peradilan tertinggi mempunyai arti dan kedudukan karena menjadi pedoman bagi pengadilan di bawahnya.

Dalam konteks ini jika mengacu pada pendapat Bellefroid (Mertokusumo, 2014: 5) mengenai asas hukum, bahwa asas hukum 
umum adalah norma dasar yang dijabarkan dari hukum positif dan yang oleh ilmu hukum tidak dianggap berasal dari aturan aturan yang lebih umum karena asas hukum itu merupakan pengendapan hukum positif dalam suatu masyarakat. Artinya bahwa dalam hal ini Penetapan Nomor 1/Pen/Pdt/Eks/2017/PN.Mbo benar-benar mengesampingkan asas hukum dan konstruksi hukum yang berlaku sehingga tercipta ketidakteraturan hukum.

Ketidakteraturan hukum ini dikenal dalam chaos theori of law. Pemahaman ketidakteraturan hukum ini mengacu pada skema hubungan antara peraturan perundangan dan penegakan hukum. Skema dan hubungan hukum yang dirumuskan dengan eksplisit dalam aturan hukum tidak menghilangkan sifat cair di belakangnya, artinya terdapat interaksi antar manusia yang menentukan makna di balik teks hukum yang ditafsirkan kembali oleh konteksnya. Pada akhirnya yang muncul adalah keadaan yang kompleks, cair, dan penuh ketidakteraturan. Dalam situasi demikian teks hukum tidak dapat berjalan sendiri secara matematis, justru ia harus berani berhadapan pada konteks yang penuh ketidakmungkinan, bukan berarti melemahkan posisi hukum tetapi hendak melampaui cara berpikir yang begitu dominan dalam mengartikan peraturan perundangundangan (Faisal, 2014: 132).

Samford tokoh chaos theori of law mengembangkan teori chaos dalam hukum dengan berpijak pada kekuasaan yang rumit dan menimbulkan situasi di mana masyarakat tidak dapat dilihat sebagai sesuatu yang bersifat sistemik dan mekanistik. Menurut Samford (Faisal, 2014: 132) ketidakteraturan dan ketidakpastian merupakan reproduksi dari relasi yang bertumpu pada hubungan antar kekuatan, hubungan tersebut tergambar dalam praktik dominasi yang melestarikan kesenjangan antara hubungan formal dan hubungan nyata yang ada dalam masyarakat sehingga ketidakteraturan hukum terjadi.

Ketidakteraturan hukum ini dapat dibaca sebagai sesuatu yang positif maupun sesuatu yang negatif. Dapat dimaknai sebagai sesuatu yang positif bila ketidakteraturan hukum ini muncul di antara praktik hukum yang tidak baik sehingga ketidakteraturan hukum ini bisa membuat stimulan yang memperbaiki relasi antara penegakan hukum dan peraturan perundangan melalui refleksi ketidakteraturan hukum tersebut. Ketidakteraturan hukum dapat dibaca sebagai sesuatu yang negatif bila ketidakteraturan tersebut merusak tata hukum, asas, dan pola relasi perundangan dan penegakan hukum yang sudah berjalan dengan baik dan penegak hukum dapat mengimplementasikan hukum sebagaimana fungsinya dalam kehidupan bermasyarakat.

Penetapan Nomor 1/Pen/Pdt/Eks/2017/ PN.Mbo bila digunakan sebagai acuan atau preseden perkara-perkara yang lain akan menimbulkan chaos yang negatif dalam tata hukum. Chaos yang negatif dalam tata hukum tersebut dikenal sebagai chaos yang destruktif (negative chaos). Negative chaos adalah chaos yang menjurus pada kesesatan, kehancuran, dan kesengsaraan yang muncul karena ada kesengajaan untuk mereduksi keutuhan realitas hukum baik yang terkait dengan pendekatannya, ruang lingkupnya, objek kajiannya (Sudjito, 2006: 165).

Terbitnya Penetapan Nomor 1/Pen/ Pdt/Eks/2017/PN.Mbo adalah persis sama dengan fenomena destruktif chaos. Fenomena destruktif chaos yaitu hukum dalam keutuhannya sebagai tatanan kehidupan direduksi menjadi 
konsep hukum yang sempit dan berkiblat pada kepentingan yang sempit pula, misalnya ketika hukum diidentikkan dengan hukum positif saja atau hukum dikonsepkan sebagai aparat penegak hukum, pereduksian tersebut ada dan disengaja dilakukan baik secara implisit maupun eksplisit namun juga tidak jarang melalui rekayasa yang canggih yang tidak bisa diamati orang lain dengan akal maupun inderawi (Sudjito, 2006: 165).

Apabila Penetapan Nomor 1/Pen/Pdt/ Eks/2017/PN.Mbo dipandang sebagai praktik baru penerapan hukum maka akan terjadi sebagai apa yang disebut turbulensi hukum. Apabila dalam masyarakat terdapat tanda-tanda ketidakstabilan serta keacakan (randomness) proses sosial dalam berbagai dimensi maka dapat disimpulkan terjadi chaos, situasi chaos yang sebenarnya terjadi dengan sebutan turbulensi yaitu suatu keadaan antara atau sebuah tapal batas antara keadaan kacau dengan keadaan teratur (Sudjito, 2006: 168).

Penetapan nomor tunggakan perkara di Mahkamah Agung menimbulkan implikasi pada fungsi Mahkamah Agung yang sebenarnya yaitu memeriksa kasus-kasus penting yang relevan dengan fungsinya menjaga kesatuan penerapan hukum, namun saat ini Mahkamah Agung lebih berorientasi pada kuantitas pemutusan perkara sehingga berdampak pada kualitas jalanya peradilan di Indonesia (Ariadi et al., 2016: 3).

Mahkamah Agung dalam hal ini harus mengambil peranan untuk merubah negative chaos ke arah positive chaos. Mengingat secara umum sudah terjadi kesimpangsiuran praktik penegakan hukum dan secara khusus bahwa Penetapan Nomor 1/Pen/Pdt/Eks/2017/PN.Mbo dapat mengganggu kelestarian sumber daya alam yang diperlukan untuk kelangsungan hajat hidup orang banyak.

\section{KESIMPULAN}

Penetapan Nomor 1/Pen/Pdt/Eks/2017/ PN.Mbo tidak dapat dibenarkan karena menyimpangi prosedur hukum acara yang berlaku, mengingat penerbitannya tidak sesuai dengan kaidah hukum dan norma hukum acara yang berlaku. Model penetapan pengadilan serupa sebagaimana Penetapan Nomor 1/Pen/ Pdt/Eks/2017/PN.Mbo harus dilakukan kajian dan dikembalikan pada kaidah hukum acara yang berlaku oleh Mahkamah Agung, sehingga tidak menjadi pola baru dalam tata hukum acara Indonesia.

Lebih lanjut dalam hal ini Mahkamah Agung atas permohonan pihak terkait dalam hal ini Kementerian Lingkungan Hidup dan Kehutanan harus melakukan langkah korektif pada perkara ini dengan membatalkan Penetapan Nomor 1/Pen/Pdt/Eks/2017/PN.Mbo dan segera melakukan eksekusi atas putusan Mahkamah Agung. Terhadap Penetapan Nomor 1/Pen/ Pdt/Eks/2017/PN.Mbo harus segera dilakukan langkah korektif untuk menghindari penetapan tersebut akan menjadi yurisprudensi yang merusak hukum acara yang berlaku dan justru menimbulkan ketidakpastian hukum.

\section{SARAN}

1. Mahkamah Agung dalam fungsinya sebagai pengawas jalannya peradilan seharusnya memberi catatan khusus pada perkara ini, khususnya Penetapan Nomor 1/Pen/Pdt/ Eks/2017/PN.Mbo karena sangat berpotensi menjadi kontra-produktif dengan semangat penegakan hukum. Mahkamah Agung harus menindaklanjuti dengan segera untuk menerbitkan surat edaran Mahkamah Agung maupun peraturan agar Penetapan 
Nomor 1/Pen/Pdt/Eks/2017/PN.Mbo tidak dipandang sebagai pola baru dalam tata hukum Indonesia sebagai bentuk upaya hukum terhadap eksekusi.

2. Negara melalui Kementerian Lingkungan Hidup dan Kehutanan harus mengajukan upaya hukum perlawanan untuk membatalkan Penetapan Nomor 1/Pen/ Pdt/Eks/2017/PN-.Mbo sebagai langkah korektif agar tidak terulang dan menjadi pola baru yang kontra-produktif dengan semangat penegakan hukum dalam tata hukum Indonesia.

\section{DAFTAR ACUAN}

Afriana, A., \& Fakhriah, E.L. (2016, Juli-Desember). Inklusifitas penegakan hukum lingkungan melalui tanggung jawab mutlak: Suatu tinjauan terhadap gugatan kebakaran hutan di Indonesia. Jurnal Hukum Acara Perdata, 2(2), 271-288.

Anshori, A.G. (2015). Filsafat hukum. Cetakan VII. Yogyakarta: Gadjah Mada University Press.

Ariadi, B.S., Usanti, T.P., \& Wahyudi, J. (2016, Februari). Peran lembaga peradilan dalam pembatasan upaya hukum dalam perkara perdata. Jurnal Mimbar Hukum, 28(1), 1-16

Bachir, D. (2015). Eksekusi putusan perkara perdata: Segi hukum \& penegakan hukum. Cetakan XIII. Jakarta: Akademika Presindo.

Chandera, H., \& Tjandra, W.R. (2012). Pengantar praktis penanganan perkara Pperdata. Cetakan XI. Yogyakarta: Universitas Atma Jaya Yogyakarta.

Elmiyah, N., \& Sujadi, S. (2005, Juli-September). Upaya-upaya hukum terhadap penetapan.
Jurnal Hukum dan Pembangunan, 35(3), 326350

Faisal. (2014, Mei-Agustus). Menelusuri teori chaos dalam hukum melalui paradigma critical legal theory. Jurnal Yustisia, 3(2),131 - 138

Fuady, M. (2012). Aliran hukum kritis. Cetakan VI. Bandung: PT Citra Aditya Bakti.

Harahap, M.Y. (2014). Hukum acara perdata tentang gugatan, persidangan, penyitaan, pembuktian \& putusan pengadilan. Cetakan V. Jakarta: Sinar Grafika.

Haris, A.M. (2016). Penerapan hukum acara perdata. Cetakan VIII. Jakarta: Kencana.

Hatta, M., \& Yustanti, D.E. (2013). Hukum acara perdata dalam tanya jawab. Cetakan III. Yogyakarta: Liberty.

Hudoyo, A.K., \& Yulianti, S.W. (2017, Mei-Agustus). Pembuktian tindak pidana lingkungan hidup pembakaran lahan secara berlanjut (Studi kasus Putusan Nomor 131/Pid.B/2013/PN.Mbo). Jurnal Hukum Verstek, 5(2), 200 - 214

Kanter. (2013). Etika profesi hukum: Sebuah pendekatan sosio-religius. Cetakan X. Jakarta: Storia Grafika.

Koespratama, S., Priyono, E.A., \& Hendrawati, D. (2016). Pertanggungjawaban perdata PT Kalista Alam atas perbuatan melawan hukum yang dilakukan dalam pembukaan lahan kebun kelapa sawit (Studi kasus Putusan Nomor 12/Pdt.G/2012/PN.Mbo). Diponegoro Law Journal, 5(3), 1-17.

Mahkamah Agung Republik Indonesia (MA RI). (2009). Pedoman pelaksanaan tugas \& administrasi pengadilan dalam empat lingkungan peradilan. Buku II. Jakarta: Mahkamah Agung. 
Makaro, M.T. (2014). Pokok-pokok hukum acara perdata. Cetakan V. Jakarta: Rineka Cipta.

Marzuki, P. (2017). Penelitian hukum. Cetakan XII. Jakarta: Prenada Media.

Mertokusumo, S. (2014). Penemuan hukum. Cetakan IX. Yogyakarta: Liberty.

Muhdar, M. (2009, Februari). Eksistensi polluter pays principle dalam pengaturan hukum lingkungan di Indonesia. Jurnal Mimbar Hukum, 21(1), 67-80.

Setiawan. (2012). Aneka masalah hukum \& hukum acara perdata. Cetakan XV. Bandung: Alumni.

Sudjito. (2006). Chaos theory of law: Penjelasan atas keteraturan \& ketidakteraturan dalam hukum. Mimbar Hukum, 18(2), 159-175.

Wantu, F.M. (2012, September). Mewujudkan kepastian hukum, keadilan \& kemanfaatan dalam putusan hakim di peradilan perdata. Jurnal Dinamika Hukum, 12(3), 479-490.

Wibisana, A.G. (2017, Juni). Keadilan dalam satu (Intra) generasi: Sebuah pengantar berdasarkan taksonomi keadilan lingkungan. Jurnal Mimbar Hukum, 29(2), 292-307. 